\title{
Determinants and Consequences of Internal Audit Functions within Colleges and Universities
}

\author{
By \\ Steven DeSimone and Kevin Rich
}

July 2019

\begin{abstract}
COLLEGE OF THE HOLY CROSS, DEPARTMENT OF ECONOMICS
FACULTY RESEARCH SERIES, PAPER NO. 19-04*
\end{abstract}

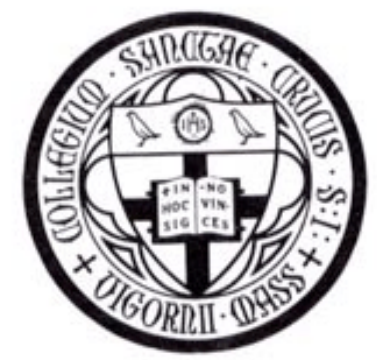

Department of Economics

College of the Holy Cross

Box 45A

Worcester, Massachusetts 01610

(508) 793-3362 (phone)

(508) 793-3708 (fax)

https://www.holycross.edu/academics/programs/economics-and-accounting

*All papers in the Holy Cross Working Paper Series should be considered draft versions subject to future revision. Comments and suggestions are welcome. 


\title{
Determinants and Consequences of Internal Audit Functions within Colleges and Universities
}

\author{
By \\ Steven DeSimone ${ }^{\dagger}$ \\ College of the Holy Cross \\ and \\ Kevin Rich ${ }^{\dagger \dagger}$ \\ Marquette University
}

July 2019

\begin{abstract}
Using a combination of publicly available and hand-collected data, this paper uses a two-stage model to first examine what drives the presence and use of internal audit functions (IAFs) at U.S. colleges and universities, and then how IAFs influence financial reporting quality (reported material weaknesses in internal controls for financial statements and federal programs) and grant outcomes therein. Results indicate that institutions receiving public funding, those with larger enrollments and endowments, and those that maintain a hospital and audit committee are more likely to maintain an IAF. Findings also suggest that the presence of an IAF is negatively associated with reported material weaknesses for major programs at significant levels. Finally, the presence of an IAF is found to have a positive and significant association with federal grants received by the institution. The study's findings provide the first quantitative insights on IAF work within U.S. colleges and universities. Results should be of interest to college/university leadership as they attempt to improve financial reporting quality and transparency, as well as grant outcomes.
\end{abstract}

Keywords: Internal auditing, colleges and universities, financial reporting quality, material weaknesses, grants

\footnotetext{
'Department of Economics and Accounting, College of the Holy Cross, 1 College Street Worcester, MA 01610, 508-793-3593 (phone), 508-793-3708 (fax), sdesimon@holycross.edu

$\dagger^{\dagger}$ Department of Accounting, Marquette University, 1225 W. Wisconsin Ave., Milwaukee, WI 53233, 414-288-7708 (phone), kevin.rich@marquette.edu
} 


\section{INTRODUCTION}

The importance of the Internal Audit Function (IAF) within U.S. publicly-traded companies is well-documented in prior literature (e.g., Abdolmohammadi et al., 2006, Cohen et al., 2006, Prawitt et al., 2009; Lin et al., 2011; Ege, 2015). The Institute of Internal Auditors (The IIA, 1999) describes internal auditing as "an independent, objective assurance and consulting activity designed to add value and improve an organization's operations. It helps an organization accomplish its objectives by bringing a systematic, disciplined approach to evaluate and improve the effectiveness of risk management, control, and governance processes" Despite this, little research has examined the role of the IAF within public sector organizations (Coupland, 1993) in the U.S. aside from municipal governments (Peterson, 2014; DeSimone, 2018), and to the authors' knowledge very little research has examined the role and impact of IAFs within U.S. colleges and universities. Using a unique set of publicly available and handcollected data, this study aims to examine both the determinants of use of IAFs in U.S. institutions of higher learning (i.e., colleges and universities) and the IAF's impact on financial reporting quality and federal grant receipts therein. As research finds that IAFs have a positive impact on financial reporting quality in both publicly-traded companies and the public sector organizations in the U.S., we expect similar outcomes for U.S. colleges and universities. Thus we seek to contribute to the literature that demonstrates the benefits of IAFs for organizations within the U.S.

Internal auditors within U.S. colleges and universities have varying responsibilities and may perform assurance and/or consultancy work. This includes but is not limited to financial, risk management, advisory, compliance (assets, grants, purchasing, and academics), and information technology work. Some colleges/universities have large system-wide or individual 
campus IAFs, some maintain one person IAFs, while others outsource IAF activities to vendors (e.g. Proviti ${ }^{1}$ ) or co-source them through consortiums (e.g. The Boston Consortium²).

In performing financial assurance work, internal auditors within colleges/universities, assist with accounting standard compliance and report findings to leadership. This is done through assessment of policies and procedures and providing ideas to improve internal controls and financial systems and reporting. In summary these IAFs:

"Review internal controls, processes, and systems to identify systemic weaknesses and propose improvements" and "Internal auditors assess the adequacy of corporate governance and the control environment; the effectiveness of processes to identify, assess, and manage risks; the assurance provided by control policies, procedures, and activities; and the completeness and accuracy of information and communication systems and practices (The IIA, 2012)."

Regarding grants, the federal government historically has been the largest sponsor of research activities at U.S. universities, contributing around $\$ 39$ billion, or 54\% of the money spent on research by universities in 2016 (NSF, 2017). ${ }^{3}$ With federally funded research grants, the principal investigator (researcher) is responsible for conducting and completing the technical (research) portion of the project, while the college/university is responsible for the project adhering to the regulations and policies of the federal funding source. Additionally, cost accounting principles and audit requirements for higher education federal award grantees are established by the U.S. Office of Management and Budget (OMB) and are detailed in The Uniform Administrative Requirements (OMB, 2014a). Internal auditors help their institutions with grant compliance by creating and/or auditing procedures and internal controls that cover

\footnotetext{
${ }^{1}$ See https://www.protiviti.com/US-en/internal-audit-and-financial-advisory.

${ }^{2}$ See http://www.boston-consortium.org/shared resources/internal audit.asp.

${ }^{3}$ There are many federal funding agencies which fund numerous research, education, training, travel, and other areas of scholarship. Some examples include: The National Institutes of Health, The National Science Foundation, The Department of Defense, The Department of Education, The National Endowment for the Arts, and the National Endowment for the Humanities. See http://www.grants.gov for a more comprehensive list.
} 
these administrative aspects of externally sponsored projects for both pre and post-award activities, and as such, can contribute to the success of obtaining and retaining grants.

However, little research has examined financial reporting of institutions of higher education, especially in the U.S., and even less regarding the IAF's contribution therein. We employ a two-stage model to first examine what drives the presence and use of IAFs in these institutions, and second how IAFs influence material weaknesses (financial and federal programs) and grant outcomes therein. Using observations from 400 colleges and universities between 2008 and 2016 (based on the largest 250 institutions by both endowment and undergraduate enrollment in 2016), we find that public institutions, those with larger enrollments and endowments, those that maintain a hospital and an audit committee are more likely to maintain an IAF. These findings imply that institutions of higher learning with more resources and that rely on public funding are likely to use an IAF to provide oversight.

Our results indicate that the presence of an IAF is negatively associated with reported material weaknesses for major programs at significant levels, but not associated with reported weaknesses in controls over financial reporting. One interpretation of this result is that IAFs focus their efforts on compliance with federal rules over major programs, and that their oversight strengthens the reporting system in a way that mitigates internal control weaknesses.

Furthermore, we find that the presence of an IAF has a positive and significant association with federal grants received by the institution. We attribute this result to improved oversight over grant dollars when there is an active IAF, possibly because of greater attention to detail during the grant application process, or higher evaluations of stewardship by institutions making granting decisions. 
We contribute to the literature on accounting in higher education in at least three ways. First, we are first to examine the IAF's role in higher education on a quantitative macro level. Our findings provide an important benchmark for college/university leadership looking to determine how their approach to internal audit compares with other institutions. Second, by documenting associations between IAF existence and financial reporting outcomes, we show how internal audit can facilitate the sharing of high-quality information with stakeholders. Third, our findings regarding grant funding highlight that the benefits of IAFs extend beyond financial reporting. This is important because internal audit helps increase levels of governance transparency (Archambeault et al., 2008) and improve grant processes, which should be useful amidst high levels of competition for grant dollars (Howard and Laird, 2013).

We organize the remainder of this paper as follows. We first present a brief literature review on accounting and internal audit for institutions of higher learning, followed by our hypotheses. Next is a description of our empirical methods, followed by our results. The last section provides concluding remarks.

\section{BACKGROUND AND HYPOTHESES}

\section{Literature Review}

Colleges and universities in the U.S. may be state or privately supported. Stakeholders that that provide funding to these institutions include state governments, taxpayers, private donors, tuition payers, students, and potential employers of graduates. Both public and private institutions of higher education routinely obtain federal grants for research (Montondon and Fischer, 1999). As discussed previously, these federal grants often comprise a large portion of funding for research conducted within higher education institutions, and has roughly doubled to almost $\$ 40$ billion since 2000 (NSF, 2017). 
Gordon et al., (2002) examine the factors associated with disclosure levels for both public and private institutions of higher learning without considering internal audit, and found that disclosure levels are significantly higher for large institutions (based on assets). Gordon and Fischer (2008) focus on disclosure specifically on performance, and found higher levels of reporting for larger institutions, those with greater debt levels, and those providing more advanced degrees. Furthermore, Behn et al., (2010) do find evidence suggesting high levels of transparency for entities of higher education compared to other nonprofit organizations, possibly because of familiarity with scrutiny by stakeholders.

Research regarding internal audit in higher education is limited, especially in the U.S. Montondon and Fischer (1999) examine the work of IAFs in U.S. institutions of higher education and find that they focus efforts on compliance and financial audits, but do not perform financial or program audits of academic subunits. This work largely descriptive, and does not empirically examine the impact of IAF work. However, we expect that IAFs within the U.S. to provide benefits to colleges/universities at least as much as their international counterparts. This is because prior research indicates that IAF development is more advanced in Anglo-Saxon countries primarily due to the longer IAF history therein (Sarens and Abdolmohammadi, 2011).

Outside the U.S., Blackmore (2004) suggests that internal academic audit inspection and quality control processes in the UK are close to the ISO 9000 guidelines for auditing quality management systems, but fall short in the areas of quality assurance and total quality management. Using survey data from a sample of Australian university vice chancellors Christopher (2012a) finds that IAFs are viewed as an important part of corporate governance and monitor controls effectively but lack the skills necessary to execute monitor management, operational, and performance based audits of educational institutions. Christopher (2012b) 
develops a model of the factors that influence corporate governance mechanisms, including internal auditing, in Australian public universities. Christopher (2015) finds that IAFs in public Australian universities operate under flexible structural and functional arrangements (sufficient organizational support, IAF activities, and relationship with management) that allow them to enhance governance in their respective institutions. Finally, Ntim et al., (2017): examine whether internal governance structures influence disclosure voluntary disclosures in UK higher education institutions, but only minimally use IAF resources as a variable.

\section{Hypotheses}

Recently, public colleges and universities have increasingly followed market-based public administration and corporate managerialism (Christopher, 2012a, Kezar and Eckel, 2004; Parker, 2011). This includes the shift to a more centralized and structured approach to governance (Kezar, 2005) which closely resembles that of the private sector. To assist higher education administration and trustees in ensuring effective governance, the framework under the corporate and new public management structure provides for a number of control mechanisms including an independent IAF. Within colleges and universities, IAFs assist the administrators by creating, updating, reviewing, and reporting on internal controls related to governance, and providing feedback therein (Christopher, 2012a). This includes controls related to both the financial reporting and the grant processes.

The Single Audit Act of 1984 (US Congress, 1984) and Single Audit Act Amendments of 1996 (US Congress, 1996) requires local governments, non-profit organizations, or institutions of higher education receiving certain levels of federal funding to undergo a single audit (previously called A-133 audit). ${ }^{4}$ Single audits ensure compliance with rules regarding the use of

\footnotetext{
${ }^{4}$ The threshold has increased over time from an initial cutoff of $\$ 300,000$, to $\$ 750,000$ (OMB 2014a).
} 
federal funds and whether appropriate internal controls are in place therein per the U.S. Office of Management and Budget (OMB, 2014a). The objectives of single audits are to evaluate whether entities that receive significant federal funding comply with laws, regulations, and the provisions of contract and grant agreements, and maintain internal control to provide reasonable assurance of compliance (OMB 2003). Institutions that spend $\$ 750,000$ or more in federal funds must undergo a financial statement audit (OMB, 2014a). This audit includes external auditor assessment of whether internal controls over financial reporting are designed to provide reasonable assurance regarding the reliability of financial reporting and the preparation of financial statements per Government Auditing Standards issued by the Comptroller General of the United States. When internal controls are deemed inadequate enough to create a reasonable possibility of a material misstatement of the entity's financial, material weaknesses are noted in audit reports for both single audits and financial statement audits (U.S. GAO, 2011).

Prior research suggests a positive relationship between the use of the IAF and financial reporting quality in publicly-traded companies (e.g., Prawitt et al., 2009; Lin et al., 2011; Ege, 2015). ${ }^{5}$ Using a sample of U.S. municipalities, Peterson (2014) finds no relationship between the presence of an IAF in municipalities and audit reportable condition, while DeSimone (2018) finds a significant positive relationship between the presence of an IAF and reported financial statement internal control issues (significant deficiencies) in a sample of U.S. municipalities with populations over 100,000. DeSimone (2018) also indicates a significant negative association between the presence of an IAF and financial statement restatements. The author posits that these

\footnotetext{
${ }^{5}$ Prawitt et al. (2009) find a positive relationship between IAF quality and financial reporting quality (abnormal accruals and the likelihood of just beating or meeting analyst forecast) in publicly traded firms. Lin et al. (2011) find a negative relationship between IAF quality disclosed material weaknesses. Ege (2015) finds a negative association between a composite measure of IAF quality (internal auditor competence, independence/objectivity, IAF financial work, and size) and management misconduct (financial reporting fraud, bribery, and misleading disclosure practices).
} 
results indicate that IAFs in the public sector are able to identify an ensure proper reporting of these issues and prevent related financial statement errors, but lack the resources to implement the controls to completely mitigate them. Thus, IAFs demonstrate the ability to help improve financial reporting quality, even when they lack appropriate resources therein.

If IAFs improve an institution's governance structure in a way that strengths internal controls, one consequence could be an inverse association between IAFs and internal control weaknesses. However, IAFs in higher education may not be as mature as publicly-traded companies (Montondon and Fischer, 1999), as they are not required to follow the provisions of Section 404 of Sarbanes-Oxley (U.S. Congress, 2002) ${ }^{6}$. This places doubt on whether they have been in place long enough to appropriately remedy all internal control weaknesses. If true, one consequence could be a positive relationship between IAF existence and internal control weaknesses. Therefore, we state our first hypothesis in the null as follows:

Hypothesis 1: The presence of an internal audit function will be independent of internal control material weaknesses.

Next, the benefits of IAFs to institutions of higher education are not limited to financial reporting, as they also may be an integral participant in the grant process of their respective institutions. The Uniform Administrative Requirements (OMB, 2014a) details the overarching accounting principles and audit requirements and provides the basis for determining applicable costs for federal award grantees. These requirements can be daunting on their own, plus each grant sponsor also has specific requirements. For example, pre-grant policies and procedures for

\footnotetext{
${ }^{6}$ Section 404(b) of the Sarbanes-Oxley act requires that the management of public companies assess the effectiveness of the internal controls over financial reporting and that registered public accounting firm that issues the audit report therein attest to, and report on, the assessment made by the management of the issuer (U.S. Congress, 2002). Since SOX was enacted, management for these companies have relied largely on internal auditors to ensure proper controls are in place to comply with this regulation. Therefore, IAFs in publicly traded companies are likely more mature and advanced than their counterparts in colleges/universities.
} 
the submission of proposals may require the use of specific application forms or electronic webbased systems. This may also include detailed instructions regarding page limitations on narrative sections, biographical sketches/CVs, budgets, budget justifications. Applications that do not conform to these requirements may jeopardize the proposal's success.

The researcher is responsible and accountable for the sponsored project and the college/university provides the infrastructure (generally administered through a sponsored research department) in which the investigator conducts the project. Thus, the institution provides guidance and support with regard to the development and administration of externally funded sponsored projects, which includes but is not limited to definition of roles and responsibilities regarding administration and compliance and to answer questions about institutional policies and procedures, as well as federal and other regulations. Pre-award, the institution assists faculty locate and apply for external funding (searches, proposal and budget development, reading and interpreting regulations and compliance guidelines, and proposal submissions). Post-award the institution may help with award negotiation, compliance with federal rules and regulations, assisting with technical report completion, and any modifications.

Internal auditors within colleges/universities are in a unique position to assist with advanced and value-added activities (Bou-Raad, 2000; Nagy and Cenker, 2002; The IIA, 2013), such as grants. Firstly, they have an innate knowledge of the institutions purpose, employees, and its environment. Second they are trained to assess policies and procedures, provide ways to improve operational and make recommendations to enhance efficiency and effectiveness of institutional operations. Finally, they regularly communicate findings and suggestions for improvements to relevant decision makers, and assist the implementation of improvements (Gramling et al., 2004; Nagy and Cenker, 2002; The IIA, 2013). 
Specific to the grant process, IAFs perform grant compliance auditing for their institutions. This includes validation that expenses charged to a grant are allocable, allowable, and reasonable; verification that specific compliance standards are upheld (export controls, hazardous materials, human subject management, IRB protocol, etc.). This "grant compliance auditing provides an assessment of compliance with federal and university guidelines to determine problem areas. Additionally, IAFs examine the controls and processes in place that handle a large number/scope of grants to verify that these processes will meet compliance/legal requirements. This includes collaboration with research administrators around controls in place (1st layer of defense) to strengthen the overall control environment. Finally, IAFs perform university wide controls/processing auditing, which involves controls that reside in pre/post award central offices (2nd layer of defense) to ensure they are operating appropriately. Finally, some IAFs utilize sophisticated data analysis tools to ensure conformance with compliance and legal regulations (primarily for expenses).

Thus, we expect that IAFs are able to apply both their institutional and compliance knowledge to help create processes and controls that streamline and make the grant process more efficient and effective and/or that IAF oversight control provides assurance to funders which leads to more positive granting decisions. Thus, we present our second hypothesis:

Hypothesis 2: The presence of an internal audit function will be associated with higher amounts of federal grant funding. 


\section{RESEARCH DESIGN AND RESULTS}

\section{Data and Summary Statistics}

We begin our analysis based on the 1,570 institutions of higher education that awarded bachelor's degrees in the United States using data from the Integrated Postsecondary Education Data System (IPEDS) provided by the National Center for Education Statistics (NCES). To facilitate comparability, we focus on the largest 250 institutions in terms of either undergraduate enrollment or endowment value in 2016. This restriction resulted in 400 unique institutions that are the focus of our analysis between 2008 and 2016. We then compile information on IAFs for sample institutions from websites and by contacting institutions via e-mail and/or phone when information is not available online. Other institution characteristics such as endowment value and enrollment also come from IPEDS, while highest degree awarded details are from the Carnegie Classification of Institutions of Higher Education. Lastly, we merge in details from Audit Analytics to identify internal control weaknesses and select financial information.

\section{Determinants of Internal Audit Functions}

Given that maintaining an IAF is voluntary for nonprofit organizations such as institutions of higher education, there is the risk that selection bias influences any results. Therefore, we begin our analysis with a determinants model designed to model the likelihood an institution maintains an IAF as part of a Heckman (1979) two stage procedure. We use the following probit specification:

$$
\begin{aligned}
\text { IAF }_{i, j}=\alpha_{0} & +\alpha_{1} \text { Endowment }_{i, j}+\alpha_{2} \text { Total enrollment }_{i, j}+\alpha 3 \text { Graduate percentage }_{i, j} \\
& +\alpha_{4} \text { Public }_{i}++\alpha 5 \text { College }_{i}+\alpha_{6} \text { Doctoral }_{i}+\alpha_{7} \text { Masters }_{i}+\alpha_{8} \text { Land grant }_{i} \\
& +\alpha_{9} \text { Religious }_{i}+\alpha_{10} \text { Urban }_{i,}+\alpha_{11} \text { Hospital }_{i}+\alpha_{12} \text { Audit committe }_{i, j} \\
& +\Sigma \delta_{j} \text { YearF }_{i, j}+\Sigma \phi_{j} \text { StateF }_{i}+\varepsilon_{i, j}
\end{aligned}
$$

Where $I A F$ is an indicator variable equal to 1 ( 0 otherwise) for institutions with an IAF in place. Endowment represents the total logged endowment of the institution while Total enrollment 
represents the total logged number of undergraduate students enrolled. These are used as a proxy for institution size, as prior research finds that the presence of an IAF is often a resource allocation decision (Abdolmohammadi et al., 2006; Anderson et al., 2012; Christopher, 2012a, 2012b). Graduate percentage is the fraction of total enrollment that are graduate students, and is a proxy for research intensity.

Private colleges and universities are not subject to the electoral control which holds government accountable while public institutions have a unique relationship to state government, through funding and their relationship with the state auditor (Gordon et al., 2002). Prior research finds that a larger internal audit department budget for private universities despite employing fewer people than the public universities (Montondon and Fischer, 1999), and that public colleges and universities disclose financial information to a greater extent than private ones (Gordon et al., 2002). Thus, Public indicates if an institution is public (coded as 1) or private (coded as 0 ). College indicates if an institution is classified as a college (coded as 1) or university (coded as 0 ).

We use several additional measures to control for factors associated with research intensity. Doctoral and Masters are indicator variables equal to 1 ( 0 otherwise) to indicate the highest degree awarded at a given institution. Land grant identifies whether an institution is designated to receive the benefits of the Morrill Acts of 1862 and 1890, while Hospital is an indicator denoting whether the institution maintains an independent hospital.

Religious is an indicator equal to 1 for institutions with a religious affiliation, and Urban is an indicator equal to 1 ( 0 otherwise) for institutions with an urban locale code as defined by the National Center for Education Statistics. Audit committee is an indicator equal to 1 ( 0 otherwise) to denote institutions that maintain an active audit committee, which is a separate 
source of governance. Lastly, YearFE represents fiscal year fixed effects while StateFE

represents the state where the institution resides.

\section{Consequences of Internal Audit Functions}

We propose the following specification to test for associations between IAFs in higher education and internal control material weaknesses.

$$
\begin{aligned}
\text { ICW }_{i, j}=\alpha_{0} & +\alpha_{1} I_{\text {IF }_{i, j}}+\alpha_{2} \text { Endowment }_{i, j}+\alpha_{3} \text { Total enrollment }_{i, j}+\alpha_{4} \text { Graduate percentage }_{i, j} \\
& +\alpha_{5} \text { Public }_{i}+\alpha_{6} \text { Hospital }_{i}+\alpha_{6} \text { Audit committee }_{i, j}+\alpha_{7} \text { Deficit }_{i, j} \\
& +\alpha_{8} \text { Low risk audit }_{i, j}+\alpha_{9} \text { Lambda }_{i, j}+\sum \delta_{j} \text { YearFE }_{j}+\sum \phi_{j} \text { StateFE }_{i}+\varepsilon_{i, j}
\end{aligned}
$$

Where $I C W$ represents either a material weakness over a) the financial statements in general, or b) major programs. Following prior research (DeSimone, 2018; Peterson, 2014) and federal guidelines (OMB 2014b) Low risk auditee denotes whether the institution is characterized by the external auditor as low risk in the previous audit year, implying that the auditors expect few exceptions to arise during fieldwork (Petrovits, Shakespeare, and Shih 2011). Deficit indicates if an institution has a change in net assets for the year of less than 0. Lambda is the inverse Mills from the first stage of our Heckman (1979) two stage procedure based on Equation (1). All other variables are defined previously.

We propose the following specification to test for associations between IAFs in higher education and federal grant funding.

$$
\begin{aligned}
& \text { Federal Grants } s_{i, j}=\alpha_{0}+\alpha_{1} I A F_{i, j}+\alpha_{2} \text { Endowment }_{i, j}+\alpha_{3} \text { Total enrollment } i, j \\
& +\alpha_{4} \text { Graduate percentage }_{i, j}+\alpha_{5} \text { Public }_{i}+\alpha_{6} \text { Hospital }_{i} \\
& +\alpha_{7} \text { Audit committee } i, j+\alpha_{8} \text { Deficit }_{i, j}+\alpha_{8} \text { Low risk audit } i, j_{i} \\
& +\alpha_{10} L_{a m b d a} a_{i, j}+\Sigma \delta_{j} Y_{e a r F E}+\Sigma \phi_{j} S t a t e F E_{i}+\varepsilon_{i, j}
\end{aligned}
$$

Where FedGrants represents the logged total dollar amount of federal grant money received by the college/university. All other variables are as defined previously. 


\section{Results}

Table 1 provides summary statistics for the institutions in our sample. Panel A is for the entire sample, which highlights that the average endowment value is over $\$ 1.2$ billion, total enrollment is approximately 16,000 students, and federal grant funding in excess of $\$ 100$ million. A minority of institutions are public (42\%), 54\% percent offer doctoral degrees, and $21 \%$ are colleges (as opposed to universities). $72 \%$ of institutions maintain an IAF, $82 \%$ of the sample has a formal audit committee, and $84 \%$ of audits are designated as low risk. Internal control material weaknesses over both financial statements and major programs are relatively infrequent, occurring in approximately $3 \%$ of observations. Table 1 , Panel B is partitioned based on existence of an IAF, and highlights that the two subsamples are statistically different across most elements included in our analysis.

We summarize the results of our determinants model in Table 2. The findings suggest that institutions with larger endowments $($ Endowment $=0.27 ; t$-statistic $=1.81)$ and larger enrollments $($ Enrollment $=0.66 ; t$-statistic $=1.79)$ are more likely to have an IAF, possibly because they have more financial resources at stake. Furthermore, institutions that are publicly funded $($ Public $=2.39 ;$-statistic $=3.57)$, that maintain a hospital $($ Hospital $=1.47 t$-statistic $=$ 1.78 and that maintain and audit committee (Audit committee $=1.34 ;$-statistic $=3.28$ ) are also more likely to maintain IAFs. One interpretation of these results is that accountability to the public and increased complexity and/or reliance on external grant funding prompt additional governance mechanisms.

We present our results for tests of Hypothesis 1 regarding internal control material weaknesses in Table 3. The results presented in Column 1 suggest no statistical association between IAFs and material weaknesses over financial statements. However, the results in 
Column 2 imply that institutions that maintain IAFs are less likely to disclose an internal control material weakness over major programs $(I A F=-0.90 ; t$-statistic $=-2.07)$, which prompts us to reject the null hypothesis that IAFs and internal control material weaknesses are independent. One possible interpretation of this result is that IAFs serve to strengthen oversight over major programs in a way that reduces the likelihood of internal control problems. In terms of control variables, Low risk audit is associated with fewer internal control weaknesses over financial reporting and major programs. Graduate and Public all associated with more material weaknesses over both financial statements and major programs. Additionally, and Audit committee is associated with more material weaknesses over major programs. The positive associations may be due to increased complexity of operations.

We present our results for tests of Hypothesis 2 regarding federal grant funding in Table 4. The findings suggest that institutions maintaining IAFs receive higher levels of federal grants $(I A F=0.28 ; t$-statistic $=2.02)$ after controlling for other factors influencing funding decisions, consistent with our predictions. As IAFs are often asked to meet with some larger grant providers $^{7}$ to opine on the control environment, we take this finding as evidence suggesting that granting agencies view the presence of an IAF as a positive factor when making funding decisions. For other variables, Endowment size, Total enrollment, Graduate percentage, Public, Doctoral, Hospital, and Deficit, are all associated with greater levels of grant funding, possibly because of an emphasis on research activity.

We also considered the type of internal audit work performed by collecting data on whether the IAFs in our sample specifically identified involvement in the financial reporting and/or the grant processes. Of the internal audit functions in our sample, $71 \%$ of reported

\footnotetext{
7 This statement is based on a conversation between one of the authors and a CAE at a large private university in the Northeast.
} 
conducting financial work, while $58 \%$ performed grant-specific procedures. Based on these responses, we created indicator variables equal to 1 ( 0 otherwise) to denote each type of focus (IAF financial work and IAF grant work, respectively), and included them in additional specifications based on Equations 2 and 3. Table 5 presents the results of these additional analyses. The findings in columns 1 through 4 of Table 5 imply no incremental impact on material weaknesses (financial statements or major programs) from IAFs specifically identifying financial work, which supports the conclusion that merely the presence of an IAF is sufficient to elicit the improvement in oversight over major programs. However, columns 5 and 6 support the conclusion that IAF grant work and the amount of federal grants received, and that the results presented in Table 3 are driven by the IAFs performing grant work. These results further illustrate the important role IAFs play in the grant processes, and support the conclusion that IAFs facilitate structures that ensure grant applications cover all necessary administrative bases and/or granting agencies gain increased comfort awarding monies to entities that have internal audit oversight.

We also performed a set of additional tests to evaluate the robustness of our results. First, we performed our internal control weakness analyses based on equation (2) using significant deficiencies as the dependent variable, and noted similar findings for major programs although they were only significant at the $10 \%$ level. Additionally, we re-performed our federal grants test based on equation (3) using federal grants per undergraduate student to further control for institution size, and noted very similar results. 


\section{SUMMARY AND CONCLUSIONS}

The purpose of this study is to examine the determinants and consequences of IAFs at U.S. institutions of higher education. Our findings suggest that IAFs are more likely at larger institutions, those that are public, with large endowments, that maintain a hospital, and those that maintain an audit committee. This may suggest that institutions that have more resources, rely on public funding, and require additional governance mechanisms. Thus they rely on IAFs to provide oversight over resources. Furthermore, we find that IAFs are associated with significantly fewer internal control material weaknesses over major programs. Finally, we find that IAFs are associated with greater levels of federal grant funding. We interpret these findings to imply that internal audit functions are associated with improved processes related to federal funding, both in terms of reporting and funding.

Future research opportunities are available due to the limitations of the current study. First, this study focuses on one specific entity, U.S. colleges and universities. Future research may consider alternative types of organizations, such as not-for-profit organizations and states, or examine similar organizations in other countries. Second, as with all survey data, responses may be based on perceptions, and not reality. Future studies using the case study approach and/or experiments may be useful to further investigate the impact of IAFs within colleges and universities. Finally, the data does not allow for a thorough examination of IAF quality, perhaps future research can examine IAF quality and its effects on financial reporting quality and grants.

Limitations aside, we interpret our results to suggest that IAFs serve to improve financial reporting systems, which in turn gives confidence to granting agencies making allocation decisions. These findings should be of use to college/university administrators looking to improve financial reporting transparency and effectively compete for research dollars. 


\section{REFERENCES}

Abdolmohammadi, M. J., Burnaby , P. and Hass., S. (2006), "The Americas Literature Review on Internal Auditing”, Managerial Auditing Journal, Vol. 21 No. 8. pp. 835-844.

Archambeault, D.S., F.T. DeZoort, and T.P. Holt. (2008), "The Need for an Internal Auditor Report to External Stakeholders to Improve Governance Transparency", Accounting Horizons, Vol. 22, No. 4, pp. 375-388.

Anderson, U. L., Christ, M. H., Johnstone, K. M., and Rittenberg, L. E. (2012), “A post-SOX examination of factors associated with the size of IAFs", Accounting Horizons, Vol. 26, No. 2, pp. 167-191.

Behn, B.K., D.D. DeVries, and J. Lin. (2010), "The determinants of transparency in nonprofit organizations: An exploratory study", Advances in Accounting, incorporating Advances in International Accounting, Vol. 6, pp. 6-12.

Blackmore, J. A. (2004), "A critical evaluation of academic internal audit", Quality Assurance in Education, Vol. 12, No. 3, pp. 128-135.

Bou-Raad, G. (2000), "Internal auditors and a value-added approach: the new business regime", Managerial Auditing Journal, Vol. 15, No. 4, pp.182-187.

Christopher, J. (2012a), "The adoption of internal audit as a governance control mechanism in Australian public universities-views from the CEOs", Journal of Higher Education Policy and Management, Vol. 34 No. 5, pp. 529-541.

Christopher, J. (2012b), "Governance paradigms of public universities: An international comparative study", Tertiary Education and Management, Vol. 18 No. 4, pp. 335-351.

Christopher, J. (2015), "Internal audit: Does it enhance governance in the Australian public university sector?", Educational Management Administration and Leadership, Vol. 43, No. 6, pp. 954-971.

Cohen, J., Krishnamoorthy, G., and Wright., A. (2004), "The Corporate Governance Mosaic and Financial Reporting Quality", Journal of Accounting Literature: pp. 87-152.

Coupland, D. (1993), “The Internal Auditor's Role in Public Service Orientation”, Managerial Auditing Journal, Vol. 8, No. 1, pp. 3-13.

DeSimone, S. M. (2018), "Internal Audit and Financial Reporting Quality in the Public Sector", Working Paper.

Ege, M. S. (2015), “Does IAF Quality Deter Management Misconduct?”, The Accounting Review, Vol. 90 No. 2, pp. 495-97.

Government Finance Officers Association (GFOA) (2008), GFOA Recommended Practice on Audit Committees, http://www.gfoa.org/audit-committees.

Gordon, T., Fischer, M., Malone, D., and Tower, G. (2002), “A comparative empirical examination of extent of disclosure by private and public colleges and universities in the United States", Journal of Accounting and Public Policy, Vol. 21, No. 3, pp. 235-275. 
Gordon. T.P. and M. Fischer (2008), "Communicating performance: the extent and effectiveness of perforamnce reporting by U.S. colleges and universities", Journal of Public Budgeting, Accounting, and Financial Management, Vol. 20, No. 2, pp. 217-255.

Gramling, A. A., Maletta, M. J., Schneider, A., and Church, B. K. (2004), "The role of the IAF in corporate governance: A synthesis of the extant internal auditing literature and directions for future research", Journal of Accounting literature, Vol. 23, pp.194-244.

Heckman, J. (1979), "Sample selection bias as a specification error", Econometrica, Vol. 47, No. 1, pp. 153-61.

Howard, D. and F. Laird. (2013), "The New Normal in Funding University Science", Issues in Science and Technology, Vol. 30, No., pp. 71-76.

Kezar, A. (2005), "Consequences of radical change in governance: A grounded theory approach.”, The Journal of Higher Education, Vol. 76, No. 6, pp. 634-668.

Kezar, A., and Eckel, P.D. (2004), "Meeting today's governance challenges: A synthesis of the literature and examination of a future agenda for scholarship", The Journal of Higher Education, Vol. 75, No. 4, pp. 371-399.

Lin, S., Pizzini, M., Vargus, M., and Bardhan, I. R. (2011), "The Role of the IAF in the Disclosure of Material Weaknesses", The Accounting Review. Vol. 86 No. 1, pp. 287323.

Montondon, L. G., and Fischer, M. (1999), "University Audit Departments in the United States", Financial Accountability and Management, Vol. 15 No. 1), pp. 85-94.

Nagy, A. L., and Cenker, W. J. (2002), "An assessment of the newly defined IAF", Managerial Auditing Journal, Vol. 17, No. 3, pp. 130-137.

National Science Foundation (NSF) (2017), Universities Report Increased Federal R\&D Funding after 4-year Decline; R\&D Fields Revised for FY 2016. InfoBrief, National Center for Science and Engineering Statistics, Alexandria, VA., NSF, https://www.nsf.gov/statistics/2018/nsf18303/nsf18303.pdf

Ntim, C. G., Soobaroyen, T., and Broad, M. J. (2017), "Governance structures, voluntary disclosures and public accountability: The case of UK higher education institutions", Accounting, Auditing and Accountability Journal, Vol. 30 No. 1, pp. 65-118.

Office of Management and Budget (OMB) (2003), Circular No. A-133: Audits of States, Local Governments, and Non-Profit Organizations, Office of Management and Budget, Washington, DC.

Office of Management and Budget (OMB) (2014a), "Uniform Administrative Requirements, Costs, and Audit Requirements for Federal Awards", Title 2 C.F.R. §200.0, https://www.ecfr.gov/cgi-bin/textidx? SID=ce4e1 f0986e67c291f77699536ebb117andmc=trueandnode=pt2.1.200andrgn=di v5\#sp2.1.200.b

Office of Management and Budget (OMB) (2014b), "Criteria for a low-risk auditee", Title 2 C.F.R. $\$ 200.520$, https://www.govinfo.gov/app/details/CFR-2014-title2-voll/CFR-2014title2-vol1-sec200-520. 
Parker, L. (2011), “University corporatization: Driving redefinition”, Critical Perspectives on Accounting, Vol. 22, pp. 434-450.

Peterson, A. N. (2014), "The Impact of Municipal Governance on Cities' Audit Outcomes", Working Paper, East Carolina University.

Petrovits, C., C. Shakespeare, and Shih, A. (2011), "The causes and consequences of internal control problems in nonprofit organizations", The Accounting Review, Vol. 86, No. 1, pp. 325-357.

Prawitt, D. F., Smith, J. L., and Wood , D. A. (2009), "Internal Audit Quality and Earnings Management", The Accounting Review, Vol. 84, No. 4, pp. 1255-80.

Prawitt, D. F., Sharp, N. Y., and Wood, D. A. (2012), "Internal Audit Outsourcing and the Risk of Misleading or Fraudulent Financial Reporting: Did Sarbanes-Oxley Get It Wrong?", Contemporary Accounting Research. Vol.. 29, No. 4, pp. 1109-36.

Rich, K. T., and Zhang, J. X. (2014), "Does Audit Committee Monitoring Matter in the Government Sector? Evidence from Municipal Internal Control Quality”, Journal of Governmental and Nonprofit Accounting, Vol. 3, No. 1, pp. 58-80.

Sarens, G., \& Abdolmohammadi, M. J. (2011), 'Monitoring effects of the internal audit function: agency theory versus other explanatory variables', International Journal of

Auditing, Vol. 15, No. 1, pp. 1-20.

The Institute of Internal Auditors (1999), A Vision for the Future: Professional Practices Framework for Internal Auditing, The Institute of Internal Auditors Research Foundation, Altamonte Springs, FL.

The Institute of Internal Auditors (2012), The Role of Auditing in Public Sector Governance. Altamonte Springs, FL., http://na.theiia.org/standardsguidance/Public\%20Documents/Public_Sector_Governance1_1_.pdf.

The Institute of Internal Auditors, (2013), Standards for the Professional Practice of Internal Auditing (Standards); IPPF 1312 - External Assessments, Almonte Springs, FL., https://na.theiia.org/standardsguidance/Public\%20Documents/IPPF\%202013\%20English.pdf.

United States Congress (1984), Single Audit Act of 1984. PUBLIC LAW 98-502, http://www.gpo.gov/fdsys/pkg/STATUTE-98/pdf/STATUTE-98-Pg2327.pdf.

United States Congress (1996), Single Audit Act Amendments of 1996. PUBLIC LAW 104-156, https://www.whitehouse.gov/sites/default/files/omb/assets/about_omb/104-156.pdf.

United States Congress (2002), Sarbanes-Oxley Act of 2002, Public Law 107-204. Washington, D.C. Government Printing Office.

United States Governmental Accountability Office (U.S. GAO) (2011), Government Accounting Standards. http://www.gao.gov/yellowbook/overview 
Table 1

Summary Statistics

Panel A: Full Sample

\begin{tabular}{lccccc}
\hline Variable & Mean & P25 & Median & P75 & St. Dev \\
\hline IAF & 0.72 & 0.00 & 1.00 & 1.00 & 0.45 \\
Endowment ('000s) & $1,208,655$ & 137,904 & 357,861 & 886,781 & $3,248,273$ \\
Total enrollment & 16,356 & 3,858 & 14,648 & 24,220 & 12,985 \\
Graduate percentage & 0.23 & 0.10 & 0.21 & 0.33 & 0.17 \\
Public & 0.42 & 0.00 & 0.00 & 1.00 & 0.49 \\
College & 0.21 & 0.00 & 0.00 & 0.00 & 0.41 \\
Doctoral & 0.54 & 0.00 & 1.00 & 1.00 & 0.50 \\
Masters & 0.20 & 0.00 & 0.00 & 0.00 & 0.40 \\
Land grant & 0.09 & 0.00 & 0.00 & 0.00 & 0.28 \\
Religious & 0.19 & 0.00 & 0.00 & 0.00 & 0.39 \\
Urban & 0.61 & 0.00 & 1.00 & 1.00 & 0.49 \\
Hospital & 0.27 & 0.00 & 0.00 & 1.00 & 0.45 \\
Audit committee & 0.82 & 1.00 & 1.00 & 1.00 & 0.38 \\
Deficit & 0.29 & 0.00 & 0.00 & 1.00 & 0.45 \\
Low risk audit & 0.84 & 1.00 & 1.00 & 1.00 & 0.37 \\
MW & 0.03 & 0.00 & 0.00 & 0.00 & 0.17 \\
MW program & 0.03 & 0.00 & 0.00 & 0.00 & 0.18 \\
Federal grants ('000s) & 102,441 & 3,393 & 29,239 & 98,975 & 193,522 \\
\hline
\end{tabular}

Panel B: Sorted by IAF

\begin{tabular}{|c|c|c|c|c|c|c|c|}
\hline Variable & Mean & $\begin{array}{l}I A F=1 \\
\text { Median }\end{array}$ & St. Dev & Mean & $\begin{array}{l}I A F=0 \\
\text { Median }\end{array}$ & St. Dev & $\begin{array}{c}\text { Test of } \\
\text { Mean Diff }\end{array}$ \\
\hline Endowment ('000s) & $1,444,563$ & 349,273 & $3,759,585$ & 591,985 & 367,04 & 814,698 & $* * *$ \\
\hline Total enrollment & 20,045 & 18,455 & 12,733 & 6,715 & 2,735 & 7,553 & $* * *$ \\
\hline Graduate percentage & 0.26 & 0.24 & 0.17 & 0.13 & 0.08 & 0.16 & $* * *$ \\
\hline Public & 0.52 & 1.00 & 0.50 & 0.15 & 0.00 & 0.36 & $* * *$ \\
\hline College & 0.10 & 0.00 & 0.30 & 0.51 & 1.00 & 0.50 & $* * *$ \\
\hline Doctoral & 0.67 & 1.00 & 0.47 & 0.20 & 0.00 & 0.40 & $* * *$ \\
\hline Masters & 0.20 & 0.00 & 0.40 & 0.21 & 0.00 & 0.40 & \\
\hline Land grant & 0.11 & 0.00 & 0.32 & 0.02 & 0.00 & 0.15 & $* * *$ \\
\hline Religious & 0.15 & 0.00 & 0.36 & 0.29 & 0.00 & 0.46 & $* * *$ \\
\hline Urban & 0.69 & 1.00 & 0.46 & 0.40 & 0.00 & 0.49 & $* * *$ \\
\hline Hospital & 0.15 & 0.00 & 0.35 & 0.03 & 0.00 & 0.16 & $* * *$ \\
\hline Audit committee & 0.88 & 1.00 & 0.33 & 0.68 & 1.00 & 0.47 & $* * *$ \\
\hline Deficit & 0.28 & 0.00 & 0.45 & 0.31 & 0.00 & 0.46 & \\
\hline Low risk audit & 0.83 & 1.00 & 0.38 & 0.87 & 1.00 & 0.34 & $* *$ \\
\hline MW & 0.03 & 0.00 & 0.17 & 0.03 & 0.00 & 0.18 & \\
\hline MW program & 0.03 & 0.00 & 0.18 & 0.03 & 0.00 & 0.18 & \\
\hline Federal grants ('000s) & 135,100 & 46,284 & 216,561 & 17,059 & 2,491 & 51,858 & $* * *$ \\
\hline
\end{tabular}

This table provides descriptive statistics for all variables included in the study. Panel A is for the entire sample, while Panel B divides the sample into two subsamples based on institutions with and without IAFs. *, **, *** indicate significance at $\mathrm{p}<0.10$, 0.05 , and 0.01 in tests of mean differences between the two subsamples. Variable descriptions are in Appendix A, except Endowment, Total enrollment, and Federal grants are reported at raw values. 
Table 2

Determinants of Internal Audit Functions in Higher Education

\begin{tabular}{|c|c|}
\hline Endowment & $\begin{array}{r}0.27^{*} \\
(1.81)\end{array}$ \\
\hline Total enrollment & $\begin{array}{c}0.66^{*} \\
(1.79)\end{array}$ \\
\hline Graduate percentage & $\begin{array}{c}1.34 \\
(1.08)\end{array}$ \\
\hline Public & $\begin{array}{l}2.39^{* * *} \\
(3.57)\end{array}$ \\
\hline College & $\begin{array}{c}0.12 \\
(0.20)\end{array}$ \\
\hline Doctoral & $\begin{array}{c}1.04 \\
(1.22)\end{array}$ \\
\hline Masters & $\begin{array}{c}0.44 \\
(0.66)\end{array}$ \\
\hline Land grant & $\begin{array}{l}-0.64 \\
(-1.05)\end{array}$ \\
\hline Religious & $\begin{array}{l}-0.14 \\
(-0.25)\end{array}$ \\
\hline Urban & $\begin{array}{c}0.17 \\
(0.51)\end{array}$ \\
\hline Hospital & $\begin{array}{r}1.47^{*} \\
(1.78)\end{array}$ \\
\hline Audit committee & $\begin{array}{l}1.34 * * * \\
(3.28)\end{array}$ \\
\hline Constant & $\begin{array}{c}3.01 \\
(0.64)\end{array}$ \\
\hline $\begin{array}{l}\text { Observations } \\
\text { Pseudo R-squared }\end{array}$ & $\begin{array}{c}3,415 \\
0.44\end{array}$ \\
\hline
\end{tabular}

*** $\mathrm{p}<0.01,{ }^{* *} \mathrm{p}<0.05,{ }^{*} \mathrm{p}<0.1$ based on two-tailed tests. Robust $\mathrm{z}$-statistics in parentheses, with standard errors clustered on institution following procedures outlined by Rogers (1993). Year and state fixed effects are included but not reported.

This table presents results from a logit specification of a determinants model of IAF existence based on Equation (1). The dependent variable is an indicator variable equal to one (zero otherwise) for institutions of higher learning that maintain a distinct IAF. Variable descriptions are in Appendix A. 
Table 3

The Relation between Internal Audit Functions and Material Weaknesses in Higher Education

\begin{tabular}{|c|c|c|}
\hline & $\begin{array}{c}\text { MW Financial } \\
\text { statements } \\
{[1]}\end{array}$ & $\begin{array}{c}\text { MW Major } \\
\text { programs } \\
{[2]} \\
\end{array}$ \\
\hline IAF & $\begin{array}{c}0.14 \\
(0.42)\end{array}$ & $\begin{array}{l}-0.90 * * \\
(-2.07)\end{array}$ \\
\hline Endowment & $\begin{array}{c}0.05 \\
(0.38)\end{array}$ & $\begin{array}{c}0.19 \\
(1.49)\end{array}$ \\
\hline Total enrollment & $\begin{array}{l}-0.23 \\
(-1.17)\end{array}$ & $\begin{array}{l}-0.02 \\
(-0.08)\end{array}$ \\
\hline Graduate percentage & $\begin{array}{r}1.31^{*} \\
(1.70)\end{array}$ & $\begin{array}{l}2.75 * * * \\
(3.01)\end{array}$ \\
\hline Public & $\begin{array}{l}1.00^{* *} \\
(2.03)\end{array}$ & $\begin{array}{l}2.22 * * * \\
(4.04)\end{array}$ \\
\hline Hospital & $\begin{array}{l}-0.23 \\
(-0.67)\end{array}$ & $\begin{array}{c}0.30 \\
(0.95)\end{array}$ \\
\hline Audit committee & $\begin{array}{c}0.35 \\
(0.58)\end{array}$ & $\begin{array}{r}0.71 * \\
(1.73)\end{array}$ \\
\hline Deficit & $\begin{array}{l}0.87 * * \\
(2.47)\end{array}$ & $\begin{array}{c}-0.47 \\
(-1.20)\end{array}$ \\
\hline Low risk audit & $\begin{array}{l}-1.64 * * * \\
(-4.97)\end{array}$ & $\begin{array}{l}-2.65^{* * *} \\
(-8.78)\end{array}$ \\
\hline Lambda & $\begin{array}{l}0.72 * * * \\
(2.80)\end{array}$ & $\begin{array}{c}0.49 \\
(0.97)\end{array}$ \\
\hline Constant & $\begin{array}{l}-4.59 \\
(-1.22)\end{array}$ & $\begin{array}{l}-22.13 * * * \\
(-5.62)\end{array}$ \\
\hline $\begin{array}{l}\text { Observations } \\
\text { Pseudo R-squared }\end{array}$ & $\begin{array}{c}2,445 \\
0.11\end{array}$ & $\begin{array}{c}2,445 \\
0.29\end{array}$ \\
\hline
\end{tabular}

*** $\mathrm{p}<0.01, * * \mathrm{p}<0.05, * \mathrm{p}<0.1$ based on two-tailed tests. Robust $\mathrm{z}$-statistics in parentheses, with standard errors clustered on institution following procedures outlined by Rogers (1993). Year fixed effects are included but not reported.

This table presents results from logit specifications of internal control material weaknesses based on Equation (2). The dependent variable in column 1 is an indicator variable equal to one (zero otherwise) for audit years with material weaknesses related to the financial statements, and in columns 2 is an indicator variable equal to one (zero otherwise) for audit years with material weaknesses related to major programs. Variable descriptions are in Appendix A. 
Table 4

The Relation between Internal Audit Functions and Federal Grants in Higher Education

\begin{tabular}{|c|c|}
\hline & $\begin{array}{c}\text { Federal grants } \\
{[1]}\end{array}$ \\
\hline IAF & $\begin{array}{l}0.28 * * \\
(2.02)\end{array}$ \\
\hline Endowment & $\begin{array}{l}0.37 * * * \\
(10.52)\end{array}$ \\
\hline Total enrollment & $\begin{array}{l}0.74 * * * \\
(7.46)\end{array}$ \\
\hline Graduate percentage & $\begin{array}{l}2.49^{* * * *} \\
(6.11)\end{array}$ \\
\hline Public & $\begin{array}{l}1.37 * * * \\
(7.69)\end{array}$ \\
\hline Doctoral & $\begin{array}{l}0.28^{* *} \\
(2.04)\end{array}$ \\
\hline Hospital & $\begin{array}{l}0.66^{* * *} \\
(4.34)\end{array}$ \\
\hline Audit committee & $\begin{array}{c}0.14 \\
(1.23)\end{array}$ \\
\hline Deficit & $\begin{array}{l}0.14^{* * *} \\
(2.88)\end{array}$ \\
\hline Lambda & $\begin{array}{l}-0.26 \\
(-1.21)\end{array}$ \\
\hline Constant & $\begin{array}{c}1.27 \\
(1.24)\end{array}$ \\
\hline Observations & 3,392 \\
\hline Pseudo R-squared & 0.83 \\
\hline
\end{tabular}

*** $\mathrm{p}<0.01, * * \mathrm{p}<0.05, * \mathrm{p}<0.1$ based on two-tailed tests. Robust $\mathrm{z}$-statistics in parentheses, with standard errors clustered on institution following procedures outlined by Rogers (1993). Year and state fixed effects are included but not reported.

This table presents results from OLS specifications of logged federal grants based on Equation (3). The dependent variable is the $\log$ of federal grants received by a given institution. Variable descriptions are in Appendix A. 
Table 5

The Relation between Internal Audit Function Procedures and Outcomes in Higher Education

\begin{tabular}{|c|c|c|c|c|c|c|}
\hline & \multicolumn{2}{|c|}{ MW Fin. Statements } & \multicolumn{2}{|c|}{ MW Major Programs } & \multicolumn{2}{|c|}{ Federal Grants } \\
\hline & {$[1]$} & {$[2]$} & [3] & [4] & {$[5]$} & {$[6]$} \\
\hline IAF & & $\begin{array}{c}0.07 \\
(0.17)\end{array}$ & & $\begin{array}{l}-1.33 * * \\
(-2.23)\end{array}$ & & $\begin{array}{c}0.20 \\
(1.37)\end{array}$ \\
\hline IAF financial work & $\begin{array}{c}0.16 \\
(0.48)\end{array}$ & $\begin{array}{c}0.13 \\
(0.33)\end{array}$ & $\begin{array}{c}-0.15 \\
(-0.35)\end{array}$ & $\begin{array}{c}0.57 \\
(1.01)\end{array}$ & & \\
\hline IAF grant work & & & & & $\begin{array}{l}0.25 * * \\
(2.32)\end{array}$ & $\begin{array}{c}\text { 0.19* } \\
(1.73)\end{array}$ \\
\hline Endowment & $\begin{array}{c}0.05 \\
(0.38)\end{array}$ & $\begin{array}{c}0.05 \\
(0.38)\end{array}$ & $\begin{array}{c}0.18 \\
(1.56)\end{array}$ & $\begin{array}{c}0.20 \\
(1.59)\end{array}$ & $\begin{array}{l}0.37 * * * \\
(10.42)\end{array}$ & $\begin{array}{c}0.37 * * * \\
(10.48)\end{array}$ \\
\hline Total enrollment & $\begin{array}{l}-0.23 \\
(-1.19)\end{array}$ & $\begin{array}{l}-0.23 \\
(-1.20)\end{array}$ & $\begin{array}{c}-0.03 \\
(-0.12)\end{array}$ & $\begin{array}{c}-0.01 \\
(-0.05)\end{array}$ & $\begin{array}{l}0.73^{* * *} \\
(7.16)\end{array}$ & $\begin{array}{l}0.72 * * * \\
(7.17)\end{array}$ \\
\hline Graduate percentage & $\begin{array}{c}1.24 \\
(1.63)\end{array}$ & $\begin{array}{c}1.25 \\
(1.63)\end{array}$ & $\begin{array}{l}2.87^{* * *} \\
(3.02)\end{array}$ & $\begin{array}{l}2.59 * * * \\
(2.83)\end{array}$ & $\begin{array}{l}2.53 * * * \\
(6.25)\end{array}$ & $\begin{array}{l}2.50 * * * \\
(6.16)\end{array}$ \\
\hline Public & $\begin{array}{l}0.98^{* *} \\
(1.96)\end{array}$ & $\begin{array}{l}0.98^{* *} \\
(1.97)\end{array}$ & $\begin{array}{l}2.17 * * * \\
(3.98)\end{array}$ & $\begin{array}{l}2.19 * * * \\
(3.79)\end{array}$ & $\begin{array}{l}1.36^{* * *} \\
(7.59)\end{array}$ & $\begin{array}{l}1.35^{* * * *} \\
(7.54)\end{array}$ \\
\hline Hospital & $\begin{array}{l}-0.26 \\
(-0.71)\end{array}$ & $\begin{array}{l}-0.25 \\
(-0.69)\end{array}$ & $\begin{array}{c}0.37 \\
(1.07)\end{array}$ & $\begin{array}{c}0.21 \\
(0.60)\end{array}$ & $\begin{array}{l}0.66^{* * * *} \\
(4.25)\end{array}$ & $\begin{array}{l}0.65^{* * * *} \\
(4.26)\end{array}$ \\
\hline Audit committee & $\begin{array}{c}0.33 \\
(0.54)\end{array}$ & $\begin{array}{c}0.33 \\
(0.54)\end{array}$ & $\begin{array}{c}0.76^{*} \\
(1.82)\end{array}$ & $\begin{array}{c}0.67^{*} \\
(1.68)\end{array}$ & $\begin{array}{c}0.13 \\
(1.07)\end{array}$ & $\begin{array}{c}0.12 \\
(1.03)\end{array}$ \\
\hline Deficit & $\begin{array}{l}0.88^{* *} \\
(2.51)\end{array}$ & $\begin{array}{l}0.88^{* * *} \\
(2.47)\end{array}$ & $\begin{array}{c}-0.55 \\
(-1.38)\end{array}$ & $\begin{array}{c}-0.48 \\
(-1.19)\end{array}$ & $\begin{array}{l}0.15^{* * * *} \\
(2.98)\end{array}$ & $\begin{array}{l}0.14^{* * * *} \\
(2.84)\end{array}$ \\
\hline Low risk audit & $\begin{array}{l}-1.64 * * * \\
(-4.95)\end{array}$ & $\begin{array}{l}-1.64 * * * \\
(-4.97)\end{array}$ & $\begin{array}{l}-2.69 * * * \\
(-8.93)\end{array}$ & $\begin{array}{l}-2.65^{* * *} \\
(-8.69)\end{array}$ & & \\
\hline Doctoral & & & & & $\begin{array}{c}0.26^{*} \\
(1.79)\end{array}$ & $\begin{array}{c}0.26^{*} \\
(1.80)\end{array}$ \\
\hline Lambda & $\begin{array}{l}0.70 * * * \\
(2.85)\end{array}$ & $\begin{array}{l}0.71 * * * \\
(2.75)\end{array}$ & $\begin{array}{c}0.84^{*} \\
(1.91)\end{array}$ & $\begin{array}{c}0.51 \\
(1.01)\end{array}$ & $\begin{array}{c}-0.34 \\
(-1.58)\end{array}$ & $\begin{array}{c}-0.28 \\
(-1.34)\end{array}$ \\
\hline Constant & $\begin{array}{l}-4.48 \\
(-1.21)\end{array}$ & $\begin{array}{l}-4.50 \\
(-1.21)\end{array}$ & $\begin{array}{l}-22.82 * * * \\
(-5.83)\end{array}$ & $\begin{array}{l}-22.36^{* * *} \\
(-5.81)\end{array}$ & $\begin{array}{c}1.82 * \\
(1.74)\end{array}$ & $\begin{array}{c}1.63 \\
(1.59)\end{array}$ \\
\hline Observations & 2,445 & 2,445 & 2,445 & 2,445 & 3,392 & 3,392 \\
\hline Pseudo R-squared & 0.11 & 0.11 & 0.28 & 0.29 & 0.83 & 0.83 \\
\hline
\end{tabular}

$* * * \mathrm{p}<0.01,{ }^{* *} \mathrm{p}<0.05,{ }^{*} \mathrm{p}<0.1$ based on two-tailed tests. Robust $\mathrm{z}$-statistics in parentheses, with standard errors clustered on institution following procedures outlined by Rogers (1993). Year fixed effects are included in all specifications (not reported), and state fixed effects are also included in the specifications for federal grant

This table presents results from logit specifications of internal control material weaknesses based on Equation (2) in columns 1 through 4, where the dependent variable is an indicator variable equal to one (zero otherwise) for audit years with material weaknesses related to the financial statements (columns 1 and 2), and an indicator variable equal to one (zero otherwise) for audit years with material weaknesses related to major programs (columns 3 and 4). Columns 5 and 6 summarize results from OLS specifications of logged federal grants based on Equation (3). Variable descriptions are in Appendix A. 


\section{Appendix A \\ Variable Definitions}

\begin{tabular}{|c|c|c|}
\hline Variable & Definition & Source \\
\hline$I A F$ & $\begin{array}{l}\text { Indicator variable equal to } 1 \text { ( } 0 \text { otherwise) for institutions } \\
\text { that maintain a distinct internal audit function (IAF). }\end{array}$ & \multirow{3}{*}{ Author Survey } \\
\hline $\begin{array}{l}\text { IAF financial } \\
\text { work }\end{array}$ & $\begin{array}{l}\text { Indicator variable equal to } 1 \text { ( } 0 \text { otherwise) for institutions } \\
\text { where the IAF conducts financial work. }\end{array}$ & \\
\hline IAF grant work & $\begin{array}{l}\text { Indicator variable equal to } 1 \text { ( } 0 \text { otherwise) for institutions } \\
\text { where the IAF conducts grant work. }\end{array}$ & \\
\hline Endowment & Year-end value of institution's endowment & $\begin{array}{l}\text { IPEDS Public (F1A) / Private (F2) } \\
\text { Institutions Finance Table }\end{array}$ \\
\hline Total enrollment & 12-month total enrollment & \multirow{2}{*}{$\begin{array}{l}\text { IPEDS 12-Month Enrollment } \\
\text { (EFFY) Table }\end{array}$} \\
\hline $\begin{array}{l}\text { Graduate } \\
\text { percentage }\end{array}$ & $\begin{array}{l}\text { Fraction of 12-month total enrollment that are graduate } \\
\text { students }\end{array}$ & \\
\hline Public & $\begin{array}{l}\text { Indicator variable equal to } 1 \text { ( } 0 \text { otherwise) for institutions } \\
\text { that are publicly administered. }\end{array}$ & $\begin{array}{l}\text { IPEDS Public (F1A) Institutions } \\
\text { Finance Table }\end{array}$ \\
\hline College & $\begin{array}{l}\text { Indicator variable equal to } 1 \text { ( } 0 \text { otherwise) for institutions } \\
\text { that do not have separate colleges. }\end{array}$ & Author judgement \\
\hline Doctoral & $\begin{array}{l}\text { Indicator variable equal to } 1 \text { ( } 0 \text { otherwise) for institutions } \\
\text { where the highest degree awarded is a Doctorate. }\end{array}$ & \multirow{2}{*}{$\begin{array}{l}\text { Carnegie Classification of } \\
\text { Institutions of Higher Education }\end{array}$} \\
\hline Masters & $\begin{array}{l}\text { Indicator variable equal to } 1 \text { ( } 0 \text { otherwise) for institutions } \\
\text { where the highest degree awarded is a Masters. }\end{array}$ & \\
\hline Land grant & $\begin{array}{l}\text { Indicator variable equal to } 1 \text { ( } 0 \text { otherwise) for land grant } \\
\text { institutions. }\end{array}$ & \multirow{3}{*}{$\begin{array}{l}\text { IPEDS Institutional Characteristics } \\
\text { - Directory Information (HD) } \\
\text { Table }\end{array}$} \\
\hline Urban & $\begin{array}{l}\text { Indicator variable equal to } 1 \text { ( } 0 \text { otherwise) for institutions } \\
\text { with a city }(11,12 \text {, or } 13) \text { locale code. }\end{array}$ & \\
\hline Hospital & $\begin{array}{l}\text { Indicator variable equal to } 1 \text { ( } 0 \text { otherwise) for institutions } \\
\text { that maintain a hospital. }\end{array}$ & \\
\hline Religious & $\begin{array}{l}\text { Indicator variable equal to } 1 \text { ( } 0 \text { otherwise) for institutions } \\
\text { with a religious affiliation. }\end{array}$ & $\begin{array}{l}\text { IPEDS Institutional Characteristics } \\
\text { - Educational Offerings, } \\
\text { Organization, Services and } \\
\text { Athletic Associations (IC) Table }\end{array}$ \\
\hline Deficit & $\begin{array}{l}\text { Indicator variable equal to } 1 \text { ( } 0 \text { otherwise) for institutions } \\
\text { with a change in net assets less than } 0 .\end{array}$ & $\begin{array}{l}\text { IPEDS Public (F1A) / Private (F2) } \\
\text { Institutions Finance Table }\end{array}$ \\
\hline Audit committee & $\begin{array}{l}\text { Indicator variable equal to } 1 \text { ( } 0 \text { otherwise) for institutions } \\
\text { that maintain an audit committee }\end{array}$ & \multirow{4}{*}{ Audit Analytics } \\
\hline Low risk audit & $\begin{array}{l}\text { Indicator variable equal to } 1 \text { ( } 0 \text { otherwise) for audit years } \\
\text { that are designated as low risk. }\end{array}$ & \\
\hline$M W$ & $\begin{array}{l}\text { Indicator variable equal to } 1 \text { ( } 0 \text { otherwise) for audit years } \\
\text { with a material weakness related to the financial statements. }\end{array}$ & \\
\hline MW program & $\begin{array}{l}\text { Indicator variable equal to } 1 \text { ( } 0 \text { otherwise) for audit years } \\
\text { with a material weakness related to major programs. }\end{array}$ & \\
\hline Federal grants & Amount of federal grants received by the institution & $\begin{array}{l}\text { IPEDS Public (F1A) / Private (F2) } \\
\text { Institutions Finance Table }\end{array}$ \\
\hline
\end{tabular}

